\title{
IHRM and expatriation in Japanese MNCs: HRM practices and their impact on adjustment and job performance
}

Article

Accepted Version

Furusawa, M. and Brewster, C. (2016) IHRM and expatriation in Japanese MNCs: HRM practices and their impact on adjustment and job performance. Asia Pacific Journal of Human Resources, 54 (4). pp. 396-420. ISSN 1744-7941 doi: https://doi.org/10.1111/1744-7941.12106 Available at https://centaur.reading.ac.uk/51153/

It is advisable to refer to the publisher's version if you intend to cite from the work. See Guidance on citing.

To link to this article DOI: http://dx.doi.org/10.1111/1744-7941.12106

Publisher: Wiley

All outputs in CentAUR are protected by Intellectual Property Rights law, including copyright law. Copyright and IPR is retained by the creators or other copyright holders. Terms and conditions for use of this material are defined in the End User Agreement.

www.reading.ac.uk/centaur 
Central Archive at the University of Reading

Reading's research outputs online 


\section{IHRM and expatriation in Japanese MNCs:}

\section{HRM practices and their impact on adjustment and job performance}

\section{Abstract:}

Studies of international human resource management have pointed out that Japanese MNCs tend to use more parent country nationals than do western MNCs. The ethnocentric staffing policies imply that the management of expatriation has a greater influence on the success of Japanese MNCs. We use survey data from 149 Japanese repatriates to examine the relationship between IHRM practices - selection, preparation and corporate support - and expatriate adjustment and job performance, as well as identify differences by the location of assignment. We find that selection criteria, language ability and familiarity with local cultures are positively related to work adjustment, and that leadership and relational abilities are slightly associated with job performance though there were no significant relationships between considerations for family situations and adjustment or job performance. The results also reveal that HRM practices while abroad, in particular the interactive exchange of information between expatriates and the headquarters, have a significant influence. Pre-departure preparation programs are not related to the dependent variables. The data also suggests that living and working in China is a particular problem for Japanese expatriates.

Key words: adjustment; China; HRM practices; Japanese expatriates; job performance

\section{Key points}

1 HRM practices extended to expatriates on duty are of critical importance to adjustment and job performance.

2 Japanese MNCs should reconsider the themes or methods of pre-departure preparation programs as none of the measures for preparation were correlated with adjustment or job performance.

3 More tailored programs for expatriates to China might be needed as some of the scores on adjustment or job performance were significantly lower for China 
compared to other countries.

\section{Introduction}

Studies of international human resource management (HRM) have pointed to the slow progress made in localizing top management positions at overseas subsidiaries of Japanese multinational corporations (Furusawa 2008; Harzing 2001, 2004; Kopp 1994, 1999). Localization might be expected to contribute to the acquisition and retention of capable human resources as well as reducing personnel costs. In addition, from an external viewpoint, it is believed to help eliminate an ethnocentric image of the company and gain access to locallyembedded knowledge (Evans, Pucik and Björkman 2011).

For Japanese MNCs, the existence of expatriates throughout the hierarchy means they have had trouble in attracting and retaining the most talented host country nationals (Keeley 2001; Kopp 1994), potentially undermining their organizational capability for local responsiveness (Isobe and Montgomerry 1999). Yoshihara (1996) found statistically significant differences in profitability between subsidiaries with a PCN president and those with an HCN president. These ethnocentric international HRM practices in Japanese MNCs have been seen as their 'Achilles heel' (Bartlett and Yoshihara 1988). Despite the criticism, Japanese MNCs keep sending Japanese expatriates to top management positions in their overseas subsidiaries (Furusawa 2008).

One strand of international human resource management studies has focused on the management of expatriation (Dowling and Schuler 1990; Stahl, Björkman and Morris 2012). The classic categorization of the motives for expatriation (Edström and Galbraith 1977) were identified as: to fill technical or managerial positions, to ensure organizational development through acting as a control and coordination mechanism, and to provide development opportunities. Later literature (Belderbos and Heijltjes 2005; Kabst 2004; Kohonen 2005; O’Donnell 2000; Selmer and Lauring 2012) found similar motives, though sometimes with a sharper focus on knowledge transfer and organizational development (Bouquet, Hebert and Delios 2004; Hocking, Brown and Harzing 2004; Mäkelä 2007). Recent texts have added the importance of developing global 
mindsets (Arora et al. 2004), representation and networking (Brewster et al. 2011).

Whatever the reasons for the expatriation, it is clear that none of them will be achieved unless the expatriate is able to adjust to their new environment and to perform well at work (Shi and Franklin 2014). Any failure of expatriation will bring a substantial loss, directly or indirectly, to the organization (Black et al. 1999; Copeland and Griggs 1985, Tungli and Peiperl 2009) and this must be especially true for Japanese MNCs, which are, compared with their western (North American and European) counterparts, heavily dependent on expatriates for managing foreign subsidiaries (Kawai and Strange 2014).

While there have been numerous studies of expatriation (Begley, Collings and Scullion 2008; Peltokorpi 2009; Takeuchi 2010), there has been comparatively little generally, and even less in the English language journals, on Japanese expatriates (Beechler et al. 2005; Belderbos and Heijltjes 2005; Furuya et al. 2007; Itagaki 2009; Kawai and Strange 2014; Yoshihara 2008). Japanese MNCs tend to use more parent country nationals in international transfers than do western MNCs (Harzing 1999; Tung 1982; Widmier, Brouthers and Beamish 2008) and their expatriates tend to stay longer in the subsidiary than expatriates from other countries (Furuya et al. 2007; Tungli and Peiperl 2009). We add to this limited literature on Japanese expatriates by examining the relationship between the HRM policies and practices extended to expatriates and their impact on adjustment and job performance. We also analyze differences in terms of the locations of assignment, since the issue of cultural distance between parent countries and host countries (Gong 2003; Kogut and Singh 1988) leads us to presume that there will be differences in the results by location.

The article takes the following form. We outline the key issues and develop hypotheses, we explain our methodology, and then present our findings. Finally, we discuss the findings and draw implications about the IHRM policies and practices of Japanese MNCs in relation to expatriation.

\section{Literature Review and Hypotheses Development}

Structural problems behind the 'rice-paper ceiling' of Japanese MNCS 
Furusawa (2008) discussed some structural problems behind the 'rice-paper ceiling' created by a heavy reliance on Japanese expatriates. These include the ethnocentricity of a country, like Japan, which is very homogeneous with the proportion of foreignborn non-naturalized workers being less than $2 \%$ of the total population (Yoshino 1976). 'Diversity management' has not been part of its national policy or social focus at least until recently. Thus Japan is unusual among developed countries and this will undoubtedly affect its companies HRM policies, including those for expatriates. Cultural homogeneity or cultural homophily creates a strong divide with dissimilar people while it eases the coordination of relations and communication among the same ethnic group (McPherson, Smith-Lovin and Cook 2001; Saeki and Horak 2014). Thus Yoshino was skeptical about the possibility that Japanese MNCs could adapt themselves to accommodate heterogeneous elements or promote localization of management, and still function effectively in the international marketplace. Yasumuro (1982) and Hayashi (1994) described this as an issue of management style, influenced by the high-context culture of Japan. High-context culture leads to a management style in which the scope of responsibilities and authority of each employee is unclear or vague. Local employees in Japanese overseas subsidiaries, who are not familiar with such a system, find it difficult to be able to manage the system effectively. Yoshihara (1989, 2008) argued that the issue was the slow progress of 'internal internationalization' or lack of international experience and thinking at headquarters. In general, the career path of top executives in Japanese MNCs has been domesticcentered, creating management teams with little overseas experience and limited foreign language capability. If the Japanese headquarters appointed local employees to top management positions at the overseas subsidiaries under these circumstances, the Japanese-only speaking headquarters would find it hard to communicate with the subsidiaries.

A recent survey of multinational corporations by Furusawa (2008) confirmed a persistence of the 'rice-paper' ceiling. Nearly three-quarters of Japanese MNCs would insist on parent country (Japanese) nationals as the presidents of overseas subsidiaries, compared to one in eight in western MNCs and, in practice, in China, local presidents were found in less than $10 \%$ of Japanese companies compared to over $80 \%$ of U. S. MNCs. These results, together with the aforementioned structural 
obstacles, suggest that Japanese MNCs are likely to maintain their ethnocentric staffing patterns, and the success of their overseas management will continue to depend on the management of Japanese expatriates.

\section{Adjustment and performance of expatriates}

The importance of managing expatriates effectively became the focus of extensive research. Much of this focused on expatriate adjustment as a key contributor to performance.

Adjustment was one of the earliest areas of expatriation to be explored (Caligiuri, Joshi and Lazarova 1999; Kraimer, Wayne and Jaworski 2001; Parker and McEvoy 1993; Shaffer, Harrison and Gilley 1999; Ward and Kennedy 1993), often suggesting a link to expatriate performance. This attention has continued into the present day (Haslberger 2005; Haslberger and Brewster 2009; Takeuchi 2010; Thomas and Lazarova 2012). Within the international HRM literature at least, the most widely used measure of adjustment has been that developed by Black and colleagues (Black, Mendenhall, and Oddou 1991; Black and Stephens 1989): A 14-item measure of adjustment based on a study with 67 participants that identified "at least three specific facets of international adjustment: (1) adjustment to work, (2) adjustment to interacting with host nationals, and (3) adjustment to the general environment" (Black, Mendenhall and Oddou 1991: 304). This model has come to dominate the business research on expatriate adjustment and there have been enough research based on it to warrant two meta-studies (Bhaskar-Shrinivas et al. 2005; Hechanova, Beehr and Christiansen 2003), though it has been subjected to persistent criticism over the years (Haslberger and Brewster 2009; Hippler 2006; Stahl and Caligiuri 2005; Thomas and Lazarova 2006).

For many the purpose of adjustment is to improve performance at work but this is not a straightforward relationship and perhaps it is not well understood (Tucker, Bonial and Lahti 2004). An inability to adjust will create psychological stress which will impact the work (Bhagat 1983; Motowidlo, Packard and Manning 1986) and therefore the literature generally assumes that

effective adjustment leads to effective performance at work (Black 1988; Black, 
Mendenhall and Oddou 1991; Kraimer and Wayne 2004; Shay and Baack 2004) though this equation has been questioned (Thomas and Lazarova 2006). Definitions of performance vary and are complicated, particularly for expatriates (Kraimer and Wayne 2004; Kraimer, Wayne and Jaworski 2001). Kawai and Strange (2014) advocate two dimensions of expatriate performance (task performance and contextual performance) and present empirical evidence that expatriate adjustment has a complete mediation effect on the relationship between perceived organizational support (Kraimer and Wayne 2004; Kraimer, Wayne and Jaworski 2001; Rhoades and Eisenberger 2002) and expatriate performance. Liu and Shaffer (2005) define expatriate performance as comprising the relational and task performance items and add knowledge transfer. Not only may performance have different interpretations, but appraiser and appraisee may either be from different cultures or, if they are from the same culture, may be long distances apart (Ng et al. 2011). Most studies to date have relied on self-reports and the same approach is applied here.

Factors that may influence adjustment and performance are selection, preparation and corporate support and it is to these that we turn in order to develop our hypotheses.

\section{Selection}

Some of the early texts (Tung 1981, 1982, 1984) pointed out that MNCs' selection criteria usually gave considerable importance to professional or technical competences rather than social or managerial skills. Other early research had noted that companies paid little attention to consideration of family issues, such as dual-career issues or education for children (Baker and Ivancevich 1971; Shaffer and Harrison 1998; Solomon 1994). More recent literature (Collings, Scullion and Dowling 2009; Mäkelä, Bjorkmann and Ehrnrooth 2009) has pointed to the complexity of global staffing, but research has tended to reinforce the earlier critiques of selection methods, reinforced by the fact that many selection systems tend to ignore their stated criteria in favor of more informal methods (Harris and Brewster 1999). There is evidence that MNCs tend to ignore personality characteristics (Caligiuri 2000; Shaffer et al. 2006) and 
language skills (Caligiuri and Tarique 2006; Peltokorpi 2009), for example, in favor of technical expertise and previous track record in the occupation. Hence, the following hypotheses:

【Hypothesis 1a】 As selection criteria, language ability and familiarity with local cultures, human skills like leadership and relational abilities, and consideration for family situations have more positive influences on the adjustment of expatriates than professional or technical competences.

【Hypothesis 1b】 As selection criteria, language ability and familiarity with local cultures, human skills like leadership and relational abilities, and consideration for family situations have more positive influences on job performance of expatriates than professional or technical competences.

\section{Preparation}

Adjustment will start as a form of anticipatory adjustment before leaving the home country. For instance, if a Japanese expatriate knows in advance that the location of assignment is a country where people drive on the right-hand side of the road, he or she can make a mental adjustment prior to expatriation (Black et al. 1999). This implies the importance of pre-departure preparation programs, along with international experiences in the past, in order to form the anticipatory adjustment (Black et al. 1999; Black, Mendenhall and Oddou 1991).

The literature on preparation (Ehnert and Brewster 2008; Mendenhall et al. 2004) has confirmed the findings of the earlier research (Tung 1981, 1982, 1984) that there is a widespread lack of preparation. As Tung pointed out, if the assumption is that technical competence is the key to success and expatriates have been selected on that criterion then further training is illogical. However, results are equivocal: Some authors make assumptions about its value (Briscoe and Schuler 2004), others have found positive effects (Waxin and Panaccio 2005) and yet others have found inconclusive results (Puck, Kittler and Wright 2008; Tarique and Caligiuri 2009). On balance we tested the following hypotheses: 
【Hypothesis 2a】 Provision of pre-departure preparation programs are associated with increasing level of expatriate adjustment.

【Hypothesis 2b】 Provision of pre-departure preparation programs are associated with increasing level of expatriate job performance.

\section{Corporate support}

It has been argued that expatriate outcomes such as adjustment and performance are dependent on the extent of corporate support to the expatriate (Grant-Vallone and Ensher 2001; Kraimer, Wayne and Jaworski 2001; Li and Jackson, 2015). In the case of Japanese expatriates, the positions at overseas subsidiaries are higher by 1.9 ranks on average than those back home (Japan Institute for Labor Policy and Training 2008). The pressures will be commensurately higher. Organizational support factors can include training during the assignment, support with finding accommodation or education for children and social support from collaborative colleagues. Such organizational support comes from both the parent company and the foreign facility (Aycan 1997; Kraimer, Wayne and Jaworski 2001). This leads to the following hypotheses:

【Hypothesis 3a】 There is a positive association between supportive HRM practices or measures while abroad and expatriate adjustment.

【Hypothesis 3b】 There is a positive association between supportive HRM practices or measures while abroad and expatriate job performance.

\section{Methodology}

The hypotheses were tested using data collected through a survey of 149 Japanese repatriates. The survey was sent to 21 Japanese companies in membership of a study meeting sponsored by Kansai Productivity Center (a nonprofit think tank in Osaka, Japan). All the companies apart from one were categorized as 'large company' by the standards of Companies Act in Japan, so they are believed to represent a cohort of leading Japanese MNCs. Each 
company was asked to find 5 to 10 former expatriates to mainland China, other Asian countries, North America, or Europe who met the following three conditions. First, their sojourn abroad had to have lasted at least two years (to ensure that most people would have reached the 'mastery stage' in their new country). Second, they had been assigned as management executives or managers (expatriates who were specialists or trainees were excluded to ensure consistency). Third, they had returned from the assignment within the last five years (a period set to minimize the influences of changes of environment surrounding the companies and expatriates and to reduce the problems of fading memory).

Apart from the demographic questions, all questions in the survey were designed to be answered using a 5-point Likert-type scale. For selection criteria, four items were identified based on descriptions of expatriation failures. Respondents were asked to what extent they thought each item was considered in the selection process. The scale ranged from $1=$ "not considered at all' to $5=$ =highly considered'. Pre-departure preparation programs and supportive measures for expatriates on duty were operationalized through a fourteen-item scale for each. For preparation, the items were developed based on earlier literature and included questions concerning training on language, HRM, local culture and values, risk management, corporate philosophy, CSR, and so on. Items on the explanation of roles, responsibilities and authorities as well as personnel evaluation and reward system, which were expected to reduce role ambiguity and role conflict (Jackson and Schuler 1985; Okamoto and Teo 2012), were also included. Similarly, the questions on corporate support also followed previous studies and asked about regular visits by the personnel department and/ or labor union of the headquarters for consultation, which is a common practice among some major Japanese MNCs. Through those questions, we assessed the perceived organizational support and the extent to which respondents agreed that those HRM practices were applied using a five-point scale ranging from $1=$ 'not provided sufficiently at all' to $5=$ 'sufficiently provided'. Concerning adjustment, the questions examined the three facets of work adjustment, interaction adjustment and general adjustment (Black et al. 1999). 
Regarding job performance, questions asked about self-reporting evaluations by supervisors, colleagues and subordinates, and the expatriates themselves. The scale for the questions on adjustment and job performance ranged from $1=$ 'entirely incorrect' to $5=$ 'exactly correct'. Analysis of variance was utilized to measure the differences by the locations of assignment in the descriptive statistics.

We tested our hypotheses using multiple-regression analysis. The possible selection criteria for expatriates, pre-departure preparation programs, and supportive measures for expatriates on duty were taken as the independent variables. Factor analysis grouped the respective items of preparation and corporate support into closely-related practices and, as a result, three factors with eigenvalues greater than 1.00 were extracted for each of these two categories of HRM practices (See Appendices 1 and 2). The factors for predeparture programs were labelled provision of information on local socioeconomic situations (Factor 1), training on 'our company way' (Factor 2), and provision of information on the foreign subsidiary of assignment and confirmation of significance of the assignment as well as the meanings in career path (Factor 3). The Cronbach's coefficient alphas were 0.90, 0.81, and 0.77 respectively. In turn, each factor for supportive measures while abroad was named interactive exchange of information between expatriates and the headquarters (Factor 1), measures to promote cross-cultural understanding and to improve foreign language ability (Factor 2), and information sharing and mutual support among Japanese expatriates (Factor 3). The Cronbach's coefficient alphas were $0.83,0.67$, and 0.73 respectively.

Adjustment and performance were the dependent variables. Composite variables were created by adding up the scores of items in the three facets of adjustment. The Cronbach's coefficient alphas for the three constructs (work, interaction, and general adjustment) were $0.86,0.73$, and 0.81 respectively. We created four geographical dummies (mainland China; other Asia; North America; and Europe). We also controlled for the number of experiences of foreign assignment that the respondents had had as we anticipated that international experience in the past will accelerate anticipatory adjustment (Black et al. 1999; 
Black, Mendenhall and Oddou 1991).

The respondents were broadly typical of Japanese expatriates. All were male. The average number of experiences of foreign assignment was 1.56 $(\mathrm{SD}=0.78)$. The most recent regions of assignments were: mainland China=56, other Asian territories (including Taiwan and Hong Kong)=39, North America=29, Europe=25. The respondents had worked at the subsidiaries for 54.3 months $(\mathrm{SD}=26.40)$ on average. About a quarter of them $(23.8 \%)$ were sent there as the president or CEO and the others held executive or managerial positions.

\section{Results}

\section{Descriptive statistics}

In terms of selection criteria, the descriptive statistics showed that the respondents perceived that their 'technical or professional competencies' (3.65) was key; and the family situation (2.62) was the least considered item (Table 1). The two other categories ('language ability and familiarity with local cultures' and 'leadership and relational abilities') fell between these scores, but were significantly related to the location of the assignment, with these factors being considered least for China. The language ability finding might be related to the fact that Japanese expatriates in China usually carry on communication with host country nationals through a Japanese-Chinese interpreter (Muramatsu 2012).

\section{$==$ Table 1 approx here==}

For pre-departure preparation programs (Table 2), the highest mean was 'explanation of the assignment and roles as well as responsibilities and authorities' (3.74), followed by 'training or provision of information on our corporate philosophy or code of conduct' (3.67) and 'training or provision of information on business situations, management policies and practices of the foreign subsidiary of assignment' (3.44). The lowest was 'language training' (2.40). We found statistically significant differences in five items, with scores for China 
being the lowest. Japanese expatriates got much less preparation for going to China. The lower score of language training for China (2.04) reconfirms that Chinese fluency is not mandatory for Japanese expatriates in China.

\section{$==$ Table 2 approx here $==$}

In supportive measures while abroad (Table 3), the score of 'advice or support by senior expatriates on working and living there' exceeded 4.00. So most Japanese expatriates got such support. 'Training or provision of information on the local culture or values' was the lowest (2.11). Since the score of this item was below the midpoint in pre-departure preparation programs as well, we conclude that Japanese MNCs do not pay much attention to the cultural issues as a whole. Again, statistically significant differences between the locations of assignment were found in two items ('transfer of duties or kick-off orientation' and 'advice or support by senior expatriates on working and living there'), with the scores of expatriates in China being the lowest in both cases.

\section{$==$ Table 3 approx here==}

For the dependent variables, all the means of adjustment exceeded 3.00 (Table 4), indicating a high level of adaptability of Japanese expatriates to foreign countries. However, while more than half the items in interaction and general adjustment were above 4.00, all the scores of work adjustment were below 4.00. In terms of the locations of assignment, five score were statistically significantly the lowest for expatriates who had been working in China, for work adjustment ('adjustment to conversation and documents in foreign language'; 'adjustment to organizational climate and work procedures at the foreign subsidiary') and general adjustment ('adjustment to climate and natural features'; 'adjustment to local public security'; 'healthy mental and physical conditions').

All the means on job performance were above 3.50, unsurprisingly perhaps given that these were self-reports, though the scores for expatriates who had been in China were the lowest for every item. 


\section{$==$ Table 4 approx here==}

\section{Multiple regression analyses}

As seen in Table 5, as selection criteria, 'language ability and familiarity with local cultures' is positively related to work adjustment. It is noteworthy that the item plays a crucial role in adjustment, though Japanese MCNs do not seem to place great importance on the issue for selection or pre-departure preparation. On the other hand, 'leadership and relational abilities' are slightly associated with 'evaluation by colleagues and subordinates' whereas there were no significant relationships between 'considerations for family situations' and the three facets of adjustment or job performance. Therefore Hypotheses 1 were partially supported.

With regard to pre-departure preparation programs, none of the three factors correlated significantly with either dependent variable, therefore both elements of Hypothesis 2 were rejected.

However, the results of the multiple regression analysis indicate that 'interactive exchange of information between expatriates and the headquarters' (Factor 1 in supportive measures while abroad) was correlated with interaction and general adjustment, as well as all the items in job performance. The 'information sharing and mutual support among Japanese expatriates' (Factor 3 in supportive measures while abroad) also had significant relationships with work and general adjustment in addition to 'evaluation by their supervisors'. This highlights the importance of HRM practices while abroad when we recall the fact that the significant relationships between the other two independent variables (selection criteria and pre-departure preparation programs) and adjustment or job performance were limited. To sum up, Hypotheses 3 were partially supported.

Contrary to our expectations, the number of times of foreign assignment had no significant relations with any of the dependent variables.

\section{$==$ Table 5 approx here $==$}


Finally, we tested the relationship between adjustment and job performance, with all three aspects of adjustment being significantly associated with all the items of job performance (Table 6). The result provided support for those who assume that adjustment precedes expatriates' job performance, though there might be some mediators such as commitment (Kawai and Strange 2014; Mol, Born and van der Molen 2005) or motivation, as we touched upon earlier.

\section{$==$ Table 6 approx here==}

\section{Discussion}

The objectives of the study were to examine the relationship between the HRM practices of Japanese MNCs as perceived by their expatriates and their impact on adjustment and job performance, as well as to analyze the differences in the results of the survey by the locations of assignment. The results confirm that some previous evidence drawn from western sources on expatriate adjustment and performance apply to Japanese expatriates as well. It also identifies specific issues created by the Japanese approach to expatriation and in particular identifies a special problem with expatriation from Japan to the Chinese mainland.

The first finding of this work concerns selection criteria. Language ability and cross-cultural competence as well as soft skills like leadership and relational abilities are, as they are with studies of western MNCs, positively related to adjustment or job performance. However, there were no significant correlations between considerations for family situations and the two dependent variable, perhaps because 'Tanshin-funin' (taking up a new post and leaving one's family behind) is common among Japanese expatriates. However, 'Tanshin-funin' could cause mental stress for employees including feelings of instability, loneliness, and loss of self-confidence (Tanaka 1995).

The second concerns preparation. There have been calls for pre-departure training programs for expatriates (Waxin and Panaccio 2005) but we found no correlation between such training and adjustment or job performance, 
confirming the skepticism of another strand of the literature on this topic (Ehnert and Brewster 2008; Puck, Kittler and Wright 2008; Tarique and Caligiuri 2009). The form of training rather than its existence may explain these different findings. Given that more than half the preparation items were above the midpoint, it seems it was sufficient.

The third result is that the HRM support for expatriates is of critical importance to their adjustment and their feelings about their performance, thus providing Japanese evidence to support previous findings (Grant-Vallone and Ensher 2001; Kraimer and Wayne 2004; Li and Jackson, 2015; Rhoades and Eisenberger 2002). MNCs may try to balance the dual pressure of local adaptation and global integration (Doz, Santos and Williamson 2001; Ghoshal and Bartlett 1988), so expatriates in their overseas subsidiaries have to nurture 'global mindsets' (Bird and Osland 2004; Levy et al. 2007; Rhinesmith 1995) to balance the respect for diversity with the pursuit of global optimization. Unsurprisingly, in these circumstances, a close relationship between the expatriates on duty and headquarters, and a feeling on the part of the former that they are supported, contributes to the success of the assignment. Above all, the interactive exchange of information between expatriates and headquarters had the most significant influence. It confirms that this relationship is an important factor for developing 'dual citizen' expatriates and prevents expatriates from becoming 'uncontrollable kites' and avoids 'out of sight, out of mind' syndrome (Furusawa 2008, 2014). Supportive HRM practices are correlated with better adjustment and higher job performance.

Our empirical research results indicate particular problems peculiar to expatriation to China (Shi and Franklin 2014). China is one of the most important countries as both a low cost manufacturing site and an emerging market for Japanese MNCs. According to the Ministry of Foreign Affairs of Japan (2015), subsidiaries in China account for 48\% of the foreign Japaneseaffiliated companies. However, in China anti-Japanese sentiment is liable to erupt at any time, sometimes fuelled by diplomatic turmoil between the two countries. The expatriates are puzzled by the equivocal Chinese HRM systems under 'socialist market economy' (Cooke 2012; Furusawa 2006). For example, 
labor unions from the age of the planned economy are maintained under the control of the Communist Party even while market-oriented pay for performance systems prevail (Furusawa 2006). The unique Chinese business customs and relations with local government are difficult for expatriates (Fayol-Song 2011). Japanese expatriates to China felt they were given less pre-departure training and less support on duty than their counterparts in other countries. Whether this was because their employers assumed that transfers to a nearby country would be easier or because the problems in China reflect a long-standing animosity between the countries it is impossible to say from this research. The findings are, however, important, since some of the scores on adjustment and job performance were significantly lower for China. Here the findings add to, and to an extent explain, the long-standing literature calling for localization in China (Fayol-Song 2011; Fryxell, Butler and Choi 2004; Itagaki 2009; Lam and Yeung 2010; Wong and Law 1999).

\section{Limitations}

Like all research, this has limitations. It would have been good to have more participants, in order to better test the validity/ robustness of the model, although the numbers compare favorably with those of other studies of expatriates. The descriptive data was mainly based on the subjective perceptions of the respondents. This is a particular problem for the perceptions of performance: the use of multi-raters for performance would help but was not possible. Because of anonymity requirements we were not able to consider the influences by conventional variables such as the size or age of subsidiaries. Moreover, it was impossible to cover all potential factors influencing the expatriates' success so that the research does not, for example, encompass a link to corporate strategy or include personality factors (Peltokorpi and Froese 2014). Despite these limitations, we believe this study sheds some light on the reality of human resource management for expatriates in Japanese MNCs, adds to the literature on Japanese expatriates (Beechler et al. 2005; Belderbos and Heijltjes 2005; Furuya et al. 2007; Itagaki 2009; Kawai and Strange 2015; Yoshihara 2008), and addresses the key issues of adjustment and performance. 


\section{Implications for practice}

For HRM policies it appears that Japanese companies may need to rethink several areas. First, 'Tanshin-funin' could be a double-edged sword. The bright side is that the careers of expatriate's family members are not disrupted but the dark side is that this puts strain on the family and removes a potential support for the expatriate in what may be a stressful situation. Second, more energy could be put into 'language proficiency and cross-cultural understanding', as selection criteria, since it was significantly correlated with work adjustment. Third, a close relationship between the expatriates on duty and headquarters, and a feeling on the part of the former that they are supported, contributes to the success of the assignment. Fourth, perhaps Japanese MNCs should reconsider the themes or methods of their pre-departure preparation programs as none of the measures for preparation were correlated with adjustment or job performance. Fifth, they may need more tailored measures for their expatriates in China in accordance with previous studies indicating that pre-departure training programs in Japanese MNCs are too standardized irrespective of assignment locations (Tanaka 2005). China is not an extension of Hong Kong, Taiwan or Southeast Asian countries and the accumulated management knowhow from there does not work for Japanese subsidiaries in China. These companies should look seriously at more localization in China as previously recommended (Fayol-Song 2011; Fryxell, Butler and Choi 2004; Itagaki 2009; Lam and Yeung 2010; Wong and Law 1999).

\section{Conclusion}

We discussed the existence of structural problems to localization in Japanese MNCs, and how those obstacles have reinforced their inclination to stick to ethnocentric IHRM policy. As with western MNCs, the success of their global operations is influenced by expatriates adjustment and performance as well as the HRM practices through which they are managed. The ethnocentric Japanese staffing patterns mean that this may be more important for them though than for western MNCs. To conclude, we believe that our evidence raises some important questions for scholars of and practitioners in Japanese MNCs, 
confirming both some similarities with expatriate management elsewhere and some unique features. We call for more research on the expatriation policies and practices of Japanese companies.

\section{References}

Arora A, A Jaju, AG Kefalas and T Perenich (2004) An exploratory analysis of global managerial mindsets: A case of U.S. textile and apparel industry. Journal of International Management 10(3), 393-411.

Aycan Z (1997) Acculturation of expatriate managers: An process model of adjustment and performance. In DM Saunders and Z Aycan (eds.) New approaches to employee management 4, 1-40. JAI Press, Greenwich, CT.

Baker JC and JM Ivancevich (1971) The assignment of American executive abroad: Systematic, haphazard, or chaotic? California Management Review 13(3), 39-44.

Bartlett CA and S Ghoshal (1998) Managing across borders: The transnational solution (2 ${ }^{\text {nd }}$ ed.). Harvard Business School Press, Boston.

Bartlett CA and H Yoshihara (1988) New challenges for Japanese multinationals: Is organization adaptation their Achilles heel? Human Resource Management 27(1), 19-43.

Beechler S, V Pucik, J Stephan and N Campbel (2005) The transnational challenge: Performance and expatriate presence in the overseas affiliates of Japanese MNCs. In T Roehl and A Bird (eds.) Japanese firms in transition: Responding to the globalization challenge, 215242. Elsevier, London.

Begley A, DG Collings and H Scullion (2008) The cross-cultural adjustment of self-initiated repatriates to the Republic of Ireland labour market. Employee Relations 30(3), 264-282.

Belderbos RA and MG Heijltjes (2005) The determinants of expatriate staffing by Japanese multinationals in Asia: Control, learning and vertical business groups. Journal of International Business Studies 36(3), 341-354.

Bhagat RS (1983) Effects of stressful life events on individual performance effectiveness and work adjustment processes within organizational settings: A research model. Academy of Management Review 8(4), 660-671.

Bhaskar-Shrinivas P, DA Harrison, MA Shaffer and DM Luk (2005) Input-based and time-based models of international adjustment: Meta-analytic evidence and theoretical extensions. Academy of Management Journal 48(2), 275-281.

Bird A and JS Osland (2004) Global competencies: An introduction. In W Lane, ML Maznevski, ME Mendenhall and J McNett (eds.) The Blackwell handbook of global management: A guide to managing complexity, 57-80. Blackwell Publishing Ltd., London. 
Black JS (1988) Work role transitions: A study of American expatriate managers in Japan. Journal of International Business Studies 19(2), 277-294.

Black JS, ME Mendenhall and G Oddou (1991) Toward a comprehensive model of international adjustment: An integration of multiple theoretical perspectives. Academy of Management Review 16(2), 291-317.

Black JS, HB Gregersen, ME Mendenhall and LK Stroh (1999) Globalizing people through international assignments. Addison-Wesley Publishing Company, Reading, MA.

Black JS and GK Stephens (1989) The influence of the spouse on American expatriate adjustment and intent to stay in Pacific Rim overseas assignments. Journal of Management 15(4), 529-544.

Bouquet C, L Hebert and A Delios (2004) Foreign expansion in service industry: Separability and human capital intensity. Journal of Business Research 57(1), 35-46.

Brewster C, P Sparrow, G Vernon and E Houldsworth (2011) International human resource management. CIPD, London.

Briscoe D and R Schuler (2004) International human resource management: Policies and practices for the global enterprise ( $2^{\text {nd }}$ ed.). Routledge, New York.

Caligiuri PM (2000) Selecting expatriates for personality characteristics: A moderating effect of personality on the relationship between host national contact and cross-cultural adjustment. Management International Review 40, 61-80.

Caligiuri PM, A Joshi and M Lazarova (1999) Factors influencing the adjustment of women on global assignments. International Journal of Human Resource Management 10(2), 163179.

Caligiuri PM and I Tarique (2006) International assignee selection and cross-cultural training and development. In G Stahl and I Björkman (eds.) Handbook of research in international human resource management, 302-322. Edward Elgar, Cheltenham.

Collings DG, H Scullion and PJ Dowling (2009) Global staffing: A review and thematic research agenda. International Journal of Human Resource Management 20(6), 1253-1272.

Cooke FL (2012) Human resource management in China: New trends and practices. Routledge, London.

Copeland L and L Griggs (1985) Going international: How to make friends and deal effectively in the global marketplace. Random House, New York.

Dowling P and R Schuler (1990) International dimensions of human resource management. PWSKent Publishing, Boston.

Doz, YL, J Santos and P Williamson (2001) From global to metanational: How companies win in the knowledge economy. Harvard Business School Press, Boston.

Edström A and JR Galbraith (1977) Transfer of managers as a coordination and control strategy in multinational organizations. Administrative Science Quarterly 22(2), 248-263.

Ehnert I and C Brewster (2008) An integrative framework for expatriate preparation and training. In C Brewster, P Sparrow and M Dickmann (eds.) International human resource 
management: Contemporary issues in Europe (2nd ed.), 107-125. Routledge, London.

Evans P, V Pucik and I Björkman (2011) The global challenge: International human resource management ( $2^{\text {nd }}$ ed.). McGraw Hill-Irwin, New York.

Fayol-Song L (2011) Reasons behind management localization in MNCs in China. Asia Pacific Business Review 17(4), 455-471.

Fryxell GE, J Butler and A Choi (2004) Successful localization programs in China: An important element in strategy implementation. Journal of World Business 39(3), 268-282.

Furusawa M (2006) Zai chuugoku nikkeikigyou no shuudanteki roushikankei no kenkyuu: 'Koukai' o meguru joukyou o chuushin ni (A study on the collective industrial relations at Japanese-affiliated companies in China: From the viewpoints of company-level trade unions). Kokusai Business Kenkyuu Gakkai Nenpou (The Annual Bulletin of Japan Academy of International Business Studies) 12, 35-52.

Furusawa M (2008) Global jintekishigen kanriron (The theory of global human resource management). Hakutou Shobou, Tokyo.

Furusawa M (2014) Global talent management in Japanese multinational companies: The case of Nissan Motor Company. In A Al Ariss (ed.) Global talent management: Challenges, strategies, and opportunities, 159-170. Springer, Heidelberg.

Furuya N, MJ Stevens, A Bird, G Oddou and M Mendenhall (2007) Managing the learning and transfer of global management competence: Antecedents and outcomes of Japanese repatriate effectiveness. Journal of International Business Studies 40(2), 200-215.

Ghoshal S and CA Bartlett (1988) Creation, adoption and diffusion of innovations by subsidiaries or multinational corporations. Journal of International Business Studies 19(3), 365-388.

Gong Y (2003) Subsidiary staffing in multinational enterprises: Agency, resources, and performance. Academy of Management Review 46(6), 728-739.

Grant-Vallone EJ and EA Ensher (2001) An examination of work and personal life conflict, organizational support and employee health among international expatriates. International Journal of Intercultural Relations 25(3), 261-278.

Harris H and C Brewster (1999) The coffee machine system: How international selection really works. International Journal of Human Resource Management 10(3), 488-500.

Harzing A-WK (1999) MNE staffing policies for the managing director position in foreign subsidiaries: The results of an innovative research method. In C Brewster and H Harris (eds.) International HRM: Contemporary issues in Europe, 67-88. Routledge, London.

Harzing A-W (2001) Who's in charge: An empirical study of executive staffing practices in foreign subsidiaries. Human Resource Management 40(2), 139-158.

Harzing A-W (2004) Composing an international staff. In A-W Harzing and JV Ruysseveldt (eds.) International human resource management (2nd ed.), 251-282. SAGE Publications, London.

Haslberger A (2005) Facets and dimensions of cross-cultural adaptation: Refining the tools. Personnel Review 34(1), 85-109. 
Haslberger A and C Brewster (2009) Capital gains: Expatriate adjustment and the psychological contract in international careers. Human Resource Management 48(3), 379-397.

Hayashi K (1994) Ibunka interface keiei (Cross cultural interface corporate management). Nihonkeizaishinbun Shuppansha, Tokyo.

Hechanova R, TA Beehr and ND Christiansen (2003) Antecedents and consequences of employees' adjustment to overseas assignment: A meta-analytic review. Applied Psychology 52(2), 213-236.

Hippler T (2006) Another scandal in Bohemia? A look back on how we measure expatriate adjustment. In M Morley, N Heraty and DG Collings (eds.) New directions in expatriate research, 64-93. Palgrave Macmillan, Houndsmill.

Hocking B, M Brown and A-W Harzing (2004) Knowledge transfer perspective of strategic assignment purposes and their path-dependent outcomes. International Journal of Human Resource Management 15(3), 565-586.

Isobe T and DB Montgomery (1999) Kaigaikogaisha no genchika to tougou (Localization and integration at overseas subsidiaries). Nichigaikyou Monthly (April), 24-27.

Itagaki H (2009) Competitiveness, localization and Japanese companies in China: Realities and alternate approaches. Asia Pacific Business Review 15(3), 451-462.

Jackson SE and RS Schuler (1985) Meta-analysis and conceptual critique of research on role ambiguity and role conflict in work settings. Organizational Behavior and Human Decision Processes 36(1), 16-78

Japan Institute for Labour Policy and Training (2008). Dai-7-kai kaigaihaken kinmusha no shokugyou to seikatsu ni kansuru chousa kekka. (The result of the $7^{\text {th }}$ survey on the work and living of expatriates.) Japan Institute for Labour Policy and Training, Tokyo.

Kabst R (2004) Human resource management for international joint ventures: Expatriation and selective control. International Journal of Human Resource Management 15(1), 1-16.

Kawai N and R Strange (2014) Perceived organizational support and expatriate performance: Understanding a mediated model. International Journal of Human Resource Management 25(17), 2438-2462.

Keeley TD (2001) International human resource management in Japanese firms. Palgrave Macmillan, New York.

Kogut B and H Singh (1988) The effect of national culture on the choice of entry mode. Journal of International Business Studies 19(3), 411-432.

Kohonen E (2005) Developing global leaders through international assignments: An identity construction perspective. Personnel Review 34(1), 22-36.

Kopp R (1994) International human resource policies and practices in Japanese, European, and United States multinationals. Human Resource Management 33(4), 581-599.

Kopp R (1999) The rice-paper ceiling in Japanese companies: Why it exists and persists. In SL Beechler and A Bird (eds.) Japanese multinationals abroad: Individual and organizational learning, 107-128. Oxford University Press, New York/ Oxford. 
Kraimer ML and SJ Wayne (2004) An examination of perceived organizational support as a multidimensional construct in the context of an expatriate assignment. Journal of Management 30(2), 209-237.

Kraimer ML, SJ Wayne and RA Jaworski (2001) Sources of support and expatriate performance: The mediating role of expatriate adjustment. Personnel Psychology 54(1), 71-99.

Lam, SSK and JCK Yeung (2010) Staff localization and environmental uncertainty on firm performance in China. Asia Pacific Journal of Management 27(4), 677-695.

Levy O, S Beechler, S Taylor and NA Boyacigiller (2007) What we talk about when we talk about 'global mindset': Managerial cognition in multinational corporations. Journal of International Business Studies 38(2), 231-258.

Li N and Jackson MH (2015) Global relocation: A examination of the corporate infuence on expatriate adjustment. Asia Pacific Journal of Human Resources 53(4), 471-489.

Liu X and MA Shaffer (2005) An investigation of expatriate adjustment and performance: A social capital perspective. International Journal of Cross Cultural Management. 5(3), 235-254.

Mäkelä K (2007) Knowledge sharing through expatriate relationships: A social capital perspective. International Studies of Management and Organization 37(3), 108-125.

Mäkelä K, I Bjorkmann and M Ehrnrooth (2009) MNC subsidiary staffing architecture: Building human and social capital within an organization. International Journal of Human Resource Management 20(6), 1273-1290.

McPherson M, L Smith-Lovin and JM Cook (2001) Birds of a feather: Homophily in social networks. Annual Review of Sociology 27(1), 415-444.

Mendenhall ME, GK Stahl, I Ehnert, G Oddou, JS Osland and TM Kühlmann (2004) Evaluation studies of cross-cultural training programs: A review of the literature from 1988 to 2000. In D Landis, JM Bennett and MJ Bennett (eds.) Handbook of intercultural training, 129143. Sage, Thousand Oaks, CA.

Ministry of Foreign Affairs of Japan (2015) Kaigai zairyuu houjinsuu, shinshutsu nikkei Kigyousuu no chousa kekka (The result of the survey on the numbers of overseas Japanese residents and Japanese-affiliated companies in foreign countries). Ministry of Foreign Affairs of Japan, Tokyo.

Motowidlo SJ, JS Packard and MR Manning (1986) Occupational stress: Its causes and consequences for job performance. Journal of Applied Psychology 71(4), 618-629.

Muramatsu J (ed.) (2012) Chuugoku ni okeru nikkeikigyou no keiei (Management of Japaneseaffiliated companies in China). Hakutou Shobou, Tokyo.

Ng KY, C Koh, S Ang, JC Kennedy and KY Chan (2011) Rating leniency and halo in multisource feedback ratings: Testing cultural assumptions of power distance and individualismcollectivism. Journal of Applied Psychology 96(5), 1033-1044.

O'Donnell SW (2000) Managing foreign subsidiaries: Agents of headquarters, or an interdependent network? Strategic Management Journal 21(5), 525-548.

Okamoto K and STT Teo (2012) Role stress reduction and cultural mediators in overseas 
Japanese companies. The International Journal of Human Resource Management 23(17), 3522-3535.

Parker B and GM McEvoy (1993) Initial examination of a model of intercultural adjustment. International Journal of Intercultural Relations 17(3), 355-379.

Peltokorpi V (2009) Cross-cultural adjustment of expatriates in Japan. International Journal of Human Resource Management 19(9), 1588-1606.

Peltokorpi V and F Froese (2014) Expatriate personality and cultural fit: The moderating role of host country context on job satisfaction. International Business Review 23(1), 293-302.

Puck JF, MG Kittler and C Wright (2008) Does it really work? Reassessing the impact of predeparture cross-cultural training on expatriate adjustment. International Journal of Human Resource Management 19(12), 2182-2197.

Rhinesmith SH (1995) Open door to a global mind-set. Training and Development 49(5), 35-43.

Rhoades L and R Eisenberger (2002) Perceived organizational support: A review of the literature. Journal of Applied Psychology 87(4), 698-714.

Saeki Y and S Horak (2014) Trust and the cultivation of relation-specific skills. Evidence from a multinational automotive supplier in Japan and Germany. Management Decision 52(8), 1433-1450.

Selmer J and J Lauring (2012) Reasons to expatriate and work outcomes of self-initiated expatriates. Personnel Review 41(5), 665-684.

Shaffer MA and DA Harrison (1998) Expatriates' psychological withdrawal from international assignments: Work, nonwork, and family influences. Personnel Psychology 51(1), 87-118.

Shaffer MA, DA Harrison and KM Gilley (1999) Dimensions, determinants, and differences in the expatriate adjustment process. Journal of International Business Studies 30(3), 557-581.

Shaffer MA, DA Harrison, H Gregersen, JS Black and LA Ferzandi (2006) You can take it with you: Individual differences and expatriate effectiveness. Journal of Applied Psychology 91(1), 109-125.

Shay JP and S Baack (2004) Expatriate assignment, adjustment and effectiveness: An empirical investigation of the big picture. Journal of International Business Studies 35(3), 216-232.

Shi X and P Franklin (2014) Business expatriates' cross-cultural adaptation and their job performance. Asia Pacific Journal of Human Resources 52(2), 193-214.

Solomon CM (1994) Success abroad depends on more than job skills. Personnel Journal 73(4), 5160.

Stahl G, I Björkman and S Morris (2012) Handbook of research in international HRM (2 ${ }^{\text {nd }}$ ed.). Edward Elgar, London.

Stahl G and PM Caligiuri (2005) The effectiveness of expatriate coping strategies: The moderating role of cultural distance, position level, and time on the international assignment. Journal of Applied Psychology 90(4), 603-615.

Takeuchi R (2010) A critical review of expatriate adjustment research through a multiple stakeholder view: Progress, emerging trends and prospects. Journal of Management 36(4), 
1040-1064.

Tanaka R (2005) Nikkei takokusekikigyou ni okeru kigyounai kyouikukunren: Kaigaihakensha jizenkenshuu no kenkyuu (In-company training at Japanese MNCS: A research on predeparture training to expatriates). Soseisha, Tokyo.

Tanaka Y (1995) Tanshin-funin ni yoru kazokubunri ga kinrousha no shinriteki stress ni oyobosu eikyou: Stress hannou o chuushin to shite (Transferred employees' psychological stress due to "tanshinfunin" family separation: A study of stress responses). Shinrigaku Kenkyuu (Japanese Psychological Research) 65(6), 428-436.

Tarique I and PM Caligiuri (2009) The role of cross-cultural absorpative capacity in the effectiveness of in-country cross-cultural training. International Journal of Training and Development 13(3), 148-164.

Thomas DC and M Lazarova (2006) Expatriate adjustment and performance: A critical review. In GK Stahl and I Björkman (eds.) Handbook of research in international human resource management, 247-264. Edward Elgar, Cheltenham.

Thomas DC and M Lazarova (2012) Expatriate adjustment and performance revisited. In G Stahl, I. Bjorkmann and $\mathrm{S}$ Morris (eds.) Handbook of international human resource management (2 ${ }^{\text {nd }}$ ed.), 271-292. Edward Elgar, Cheltenham.

Tucker MF, R Bonial and K Lahti (2004) The definition, measurement and prediction of intercultural adjustment and job performance among corporate expatriates. International Journal of Intercultural Relations 28(3), 221-251.

Tung RL (1981) Selection and training of personnel for overseas assignments. Columbia Journal of World Business 16(1), 68-78.

Tung RL (1982) Selection and training procedures of US, European and Japanese multinationals. California Management Review 25(1), 57-71.

Tung RL (1984) Strategic management of human resources in the multinational enterprise. Human Resource Management 23(2), 129-143.

Tungli Z and M Peiperl (2009) Expatriate practices in German, Japanese, U.K., and U.S. multinational companies: A comparative survey of changes. Human Resource Management 48(1), 153-171.

Ward C and A Kennedy (1993) Where's the 'culture' in cross-cultural transition? Comparative studies of sojourner adjustment. Journal of Cross-Cultural Psychology 24(2), 221-249.

Waxin A and A Panaccio (2005) Cross-cultural training to facilitate expatriate adjustment: It works! Personnel Review 34(1), 51-67.

Widmier S, LE Brouthers and PW Beamish (2008) Expatriate or local? Predicting Japanese subsidiary expatriate staffing strategies. International Journal of Human Resource Management 19(9), 1607-1621.

Wong CS and KS Law (1999) Managing localization of human resources in the PRC: A practical model. Journal of World Business 34(1), 26-40.

Yasumuro K (1982) Kokusai keiei koudouron (The theory of international management behavior). 
Moriyama Shoten, Tokyo.

Yoshihara H (1989) Genchijinshachou to uchinaru kokusaika (Host country national presidents and internal internationalization). Toyo Keizai Shinposha, Tokyo.

Yoshihara H (2008) Belated change in international management of Japanese multinationals. Rikkyo Business Review 1, 4-15.

Yoshino MY (1976) Japan's multinational enterprises. Harvard University Press, Cambridge, MA. 


\section{Tables}

Table 1 Selection criteria

\begin{tabular}{|c|c|c|c|c|c|c|c|}
\hline \multirow[t]{2}{*}{ 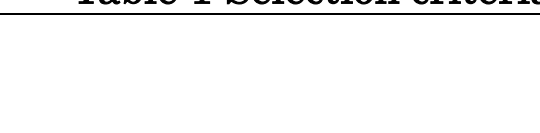 } & \multirow[b]{2}{*}{ Total } & \multirow[b]{2}{*}{$\mathrm{SD}$} & \multicolumn{4}{|c|}{ Location of assignment } & \multirow[b]{2}{*}{ F-value } \\
\hline & & & China & $\begin{array}{l}\text { Other } \\
\text { Asia }\end{array}$ & $\begin{array}{l}\text { North } \\
\text { America }\end{array}$ & Europe & \\
\hline $\begin{array}{l}\text { Language ability and familiarity } \\
\text { with local cultures }\end{array}$ & 2.86 & 1.32 & 2.45 & 2.64 & 3.45 & 3.46 & $6.293^{* * *}$ \\
\hline $\begin{array}{l}\text { Technical or professional } \\
\text { competences }\end{array}$ & 3.65 & 1.04 & 3.66 & 3.36 & 3.79 & 3.92 & 1.796 \\
\hline $\begin{array}{l}\text { Leadership and relational } \\
\text { abilities }\end{array}$ & 3.42 & 0.87 & 3.25 & 3.29 & 3.69 & 3.68 & $2.747^{*}$ \\
\hline Family situations & 2.62 & 1.17 & 2.43 & 2.54 & 3.04 & 2.72 & 1.836 \\
\hline
\end{tabular}

- Scores in the table are the means of answers on 5-point Likert-scales (5=Highly considered, $3=$

A toss-up, 1=Not considered at all).

**** : p $<0.001, * *: p<0.01, *: p<0.05, \dagger: p<0.1$.

Table 2 Pre-departure preparation programs

\begin{tabular}{|l|l||l||l|l|l|l|l|}
\hline & \multirow{2}{*}{ Total } & SD & China & $\begin{array}{l}\text { Other } \\
\text { Asia }\end{array}$ & $\begin{array}{l}\text { North } \\
\text { America }\end{array}$ & Europe & F-value \\
\hline Language training & 2.40 & 1.31 & 2.04 & 2.23 & 2.90 & 2.92 & $4.626^{* *}$ \\
\hline $\begin{array}{l}\text { Training or provision of } \\
\text { information on business } \\
\text { situations, management policies } \\
\text { and practices of the foreign } \\
\text { subsidiary of assignment }\end{array}$ & 3.44 & 1.16 & 3.27 & 3.31 & 3.79 & 3.58 & 1.589 \\
\hline $\begin{array}{l}\text { Explanation of the assignment } \\
\text { and roles as well as } \\
\text { responsibilities and authorities }\end{array}$ & 3.74 & 1.00 & 3.82 & 3.64 & 3.83 & 3.64 & 0.396 \\
\hline $\begin{array}{l}\text { Explanation of the meanings of } \\
\text { the assignment in career path }\end{array}$ & 2.68 & 1.19 & 2.43 & 2.74 & 2.93 & 2.88 & 1.563 \\
\hline $\begin{array}{l}\text { Training or provision of } \\
\text { information on local personnel } \\
\text { management or labor } \\
\text { management relations }\end{array}$ & 2.52 & 1.15 & 2.11 & 2.69 & 3.17 & 2.40 & $6.509^{* * *}$ \\
\hline $\begin{array}{l}\text { Training or provision of } \\
\text { information on local cultures or } \\
\text { values }\end{array}$ & 2.73 & 1.20 & 2.48 & 2.79 & 3.21 & 2.64 & $2.503 \dagger$ \\
\hline $\begin{array}{l}\text { Training or provision of } \\
\text { information on living in the } \\
\text { country of assignment }\end{array}$ & 3.01 & 1.13 & 2.66 & 3.03 & 3.69 & 3.00 & $5.792^{* *}$ \\
\hline $\begin{array}{l}\text { Training or provision of } \\
\text { information on risk management } \\
\text { or securities }\end{array}$ & 3.11 & 1.18 & 3.02 & 3.11 & 3.55 & 2.84 & 1.937 \\
\hline $\begin{array}{l}\text { Opportunities to visit the country } \\
\text { of assignment prior to } \\
\text { expatriation }\end{array}$ & 2.83 & 1.45 & 2.91 & 2.38 & 3.17 & 2.96 & 1.928 \\
\hline $\begin{array}{l}\text { Advice or provision of } \\
\text { information from former } \\
\text { expatriates to the country of } \\
\text { assignment }\end{array}$ & 3.41 & 1.17 & 3.15 & 3.26 & 4.17 & 3.32 & $5.812^{* * *}$ \\
\hline $\begin{array}{l}\text { Explanation of personnel } \\
\text { evaluation and reward systems }\end{array}$ & 3.40 & 1.13 & 3.30 & 3.23 & 3.79 & 3.40 & 1.611 \\
\hline $\begin{array}{l}\text { Training or provision of } \\
\text { information on our corporate } \\
\text { philosophy or code of conduct }\end{array}$ & 3.67 & 1.00 & 3.80 & 3.49 & 3.79 & 3.52 & 1.097 \\
\hline
\end{tabular}




\begin{tabular}{|l|l||l|l|l|l|l|l|l|}
\hline $\begin{array}{l}\text { Training or provision of } \\
\text { information on our basic } \\
\text { principles of personnel } \\
\text { management or labor } \\
\text { management relations }\end{array}$ & 3.02 & 1.15 & 2.93 & 2.85 & 3.55 & 2.88 & $2.677^{*}$ \\
\hline $\begin{array}{l}\text { Training or provision of } \\
\text { information on our basic } \\
\text { principles of CSR }\end{array}$ & 3.01 & 1.17 & 3.29 & 2.69 & 3.17 & 2.72 & $2.800^{*}$ \\
\hline
\end{tabular}

- Scores in the table are the means of answers on 5-point Likert-scales (5=Sufficiently provided, $3=$ A toss-up, $1=$ Not provided sufficiently at all).

Table 3 Supportive measures while abroad

\begin{tabular}{|c|c|c|c|c|c|c|c|}
\hline & \multirow[b]{2}{*}{ Total } & \multirow[b]{2}{*}{$\mathrm{SD}$} & \multicolumn{4}{|c|}{ Location of assignment } & \multirow[b]{2}{*}{$\mathrm{F}$-value } \\
\hline & & & $\begin{array}{l}\text { Chin } \\
\text { a }\end{array}$ & $\begin{array}{l}\text { Other } \\
\text { Asia }\end{array}$ & $\begin{array}{l}\text { North } \\
\text { America }\end{array}$ & Europe & \\
\hline $\begin{array}{l}\text { Transfer of duties or kick-off } \\
\text { orientation }\end{array}$ & 3.15 & $\begin{array}{c}1.3 \\
4\end{array}$ & 2.76 & 3.23 & 3.86 & 3.00 & $4.442^{* *}$ \\
\hline $\begin{array}{l}\text { Advice or support by senior } \\
\text { expatriates on working and living } \\
\text { there }\end{array}$ & 4.02 & $\begin{array}{c}1.0 \\
3\end{array}$ & 3.73 & 4.08 & 4.45 & 4.00 & $3.139 *$ \\
\hline $\begin{array}{l}\text { Supportive measures to improve } \\
\text { language ability }\end{array}$ & 2.29 & $\begin{array}{c}1.2 \\
8\end{array}$ & 2.45 & 2.26 & 2.11 & 2.20 & 0.511 \\
\hline $\begin{array}{l}\text { Training or provision of } \\
\text { information on the local cultures } \\
\text { or values }\end{array}$ & 2.11 & $\begin{array}{c}1.2 \\
1\end{array}$ & 2.05 & 2.00 & 2.45 & 2.04 & 0.937 \\
\hline $\begin{array}{l}\text { Existence of mentors or advisors } \\
\text { at the headquarters (including } \\
\text { the regional headquarters) }\end{array}$ & 2.82 & $\begin{array}{c}1.3 \\
2\end{array}$ & 2.77 & 2.74 & 2.97 & 2.92 & 0.241 \\
\hline $\begin{array}{l}\text { Supportive measures or provision } \\
\text { of information on living in the } \\
\text { country of assignment }\end{array}$ & 3.01 & $\begin{array}{c}1.1 \\
4\end{array}$ & 2.98 & 2.82 & 3.34 & 2.96 & 1.234 \\
\hline $\begin{array}{l}\text { Opportunities to make a request } \\
\text { on face-to-face basis such as } \\
\text { regular visits by personnel } \\
\text { department or labor union of the } \\
\text { headquarters }\end{array}$ & 3.09 & $\begin{array}{c}1.1 \\
2\end{array}$ & 3.02 & 3.31 & 3.28 & 2.72 & 1.761 \\
\hline $\begin{array}{l}\text { Supportive measures of } \\
\text { healthcare such as the affiliation } \\
\text { with reliable local medical } \\
\text { institutions }\end{array}$ & 3.68 & $\begin{array}{c}1.1 \\
9\end{array}$ & 3.66 & 3.69 & 3.76 & 3.60 & 0.085 \\
\hline $\begin{array}{l}\text { Support system for risk } \\
\text { management or securities }\end{array}$ & 3.30 & $\begin{array}{c}1.1 \\
2\end{array}$ & 3.13 & 3.38 & 3.66 & 3.12 & 1.729 \\
\hline $\begin{array}{l}\text { Provision of real-time information } \\
\text { on the latest management policies } \\
\text { or technical trends at the } \\
\text { headquarters }\end{array}$ & 3.26 & $\begin{array}{c}1.1 \\
9\end{array}$ & 3.18 & 3.31 & 3.55 & 3.04 & 0.977 \\
\hline Grant of paid leave to Japan & 3.72 & $\begin{array}{c}1.0 \\
6\end{array}$ & 3.59 & 3.95 & 3.69 & 3.72 & 0.897 \\
\hline $\begin{array}{l}\text { Feedback on the result of } \\
\text { personnel evaluation }\end{array}$ & 3.36 & $\begin{array}{c}1.1 \\
9\end{array}$ & 3.11 & 3.62 & 3.38 & 3.52 & 1.624 \\
\hline $\begin{array}{l}\text { Reward system in consideration } \\
\text { for hardship of the work and } \\
\text { living expenses }\end{array}$ & 3.74 & $\begin{array}{c}0.9 \\
6\end{array}$ & 3.64 & 3.90 & 3.93 & 3.48 & 1.547 \\
\hline $\begin{array}{l}\text { Explanation of jobs or career } \\
\text { prospects after repatriation }\end{array}$ & 2.62 & $\begin{array}{c}1.1 \\
4\end{array}$ & 2.52 & 2.67 & 2.83 & 2.52 & 0.554 \\
\hline
\end{tabular}

- Scores in the table are the means of answers on 5-point Likert-scales (5=Sufficiently provided, $3=$ A toss-up, $1=$ Not provided sufficiently at all). 
Table 4 Adjustment and job performance

\begin{tabular}{|c|c|c|c|c|c|c|c|}
\hline & \multirow[b]{2}{*}{ Total } & \multirow[b]{2}{*}{ SD } & \multicolumn{4}{|c|}{ Location of assignment } & \multirow[t]{2}{*}{ F-value } \\
\hline & & & China & $\begin{array}{l}\text { Other } \\
\text { Asia }\end{array}$ & $\begin{array}{l}\text { North } \\
\text { America }\end{array}$ & Europe & \\
\hline \multicolumn{8}{|l|}{ Adjustment } \\
\hline \multicolumn{8}{|l|}{ (1)Work adjustment } \\
\hline $\begin{array}{l}\text { Adjustment to conversation and } \\
\text { documents in foreign language }\end{array}$ & 3.38 & 1.26 & 2.80 & 3.72 & 3.76 & 3.72 & $7.165^{* * *}$ \\
\hline $\begin{array}{l}\text { Adjustment to organizational } \\
\text { climate and work procedures at the } \\
\text { foreign subsidiary }\end{array}$ & 3.81 & 0.91 & 3.53 & 4.00 & 3.97 & 3.96 & $2.986^{*}$ \\
\hline $\begin{array}{l}\text { Adjustment to the assignment and } \\
\text { roles as well as responsibilities and } \\
\text { authorities }\end{array}$ & 3.89 & 0.85 & 3.71 & 3.92 & 4.07 & 4.00 & 1.445 \\
\hline $\begin{array}{l}\text { Adjustment to personnel } \\
\text { management or labor management } \\
\text { relations }\end{array}$ & 3.55 & 1.04 . & 3.34 & 3.72 & 3.69 & 3.60 & 1.300 \\
\hline \multicolumn{8}{|l|}{ (2)Interaction adjustment } \\
\hline $\begin{array}{l}\text { Relationship building with other } \\
\text { Japanese expatriates at the foreign } \\
\text { subsidiary }\end{array}$ & 4.30 & 0.85 & 4.09 & 4.43 & 4.48 & 4.35 & 1.834 \\
\hline $\begin{array}{l}\text { Relationship building with local } \\
\text { employees at the foreign subsidiary }\end{array}$ & 4.30 & 0.75 & 4.25 & 4.31 & 4.28 & 4.44 & 0.379 \\
\hline $\begin{array}{l}\text { Relationship building with local } \\
\text { customers or suppliers }\end{array}$ & 4.09 & 0.80 & 4.00 & 4.19 & 3.97 & 4.28 & 1.128 \\
\hline $\begin{array}{l}\text { Relationship building with local } \\
\text { government }\end{array}$ & 3.27 & 1.02 & 3.35 & 3.11 & 3.04 & 3.65 & 2.013 \\
\hline $\begin{array}{l}\text { Relationship building with local } \\
\text { Japanese organizations }\end{array}$ & 3.68 & 1.14 & 3.70 & 3.74 & 3.55 & 3.68 & 0.153 \\
\hline $\begin{array}{l}\text { Interaction with local people on off- } \\
\text { the- job situations }\end{array}$ & 3.79 & 1.04 & 3.71 & 4.05 & 3.52 & 3.88 & 1.664 \\
\hline \multicolumn{8}{|l|}{ (3) General adjustment } \\
\hline $\begin{array}{l}\text { Adjustment to climate and natural } \\
\text { features }\end{array}$ & 4.19 & 0.76 & 4.00 & 4.31 & 4.38 & 4.24 & $2.166 \dagger$ \\
\hline $\begin{array}{l}\text { Adjustment to food and eating } \\
\text { habits }\end{array}$ & 4.13 & 0.96 & 4.07 & 4.33 & 4.00 & 4.08 & 0.851 \\
\hline Adjustment to local public security & 4.04 & 0.85 & 3.75 & 4.21 & 4.21 & 4.24 & $3.732^{*}$ \\
\hline $\begin{array}{l}\text { Healthy mental and physical } \\
\text { conditions }\end{array}$ & 3.99 & 0.96 & 3.63 & 4.31 & 4.14 & 4.12 & $4.872^{* *}$ \\
\hline \multicolumn{8}{|l|}{ Job performance } \\
\hline High evaluation from my boss & 3.63 & 0.97 & 3.38 & 3.74 & 3.93 & 3.68 & $2.505 \dagger$ \\
\hline $\begin{array}{l}\text { High evaluation from my colleagues } \\
\text { and subordinates }\end{array}$ & 3.81 & 0.77 & 3.64 & 3.87 & 3.90 & 4.00 & 1.632 \\
\hline $\begin{array}{l}\text { High self-evaluation of my job } \\
\text { performance }\end{array}$ & 3.74 & 0.98 & 3.61 & 3.82 & 3.83 & 3.80 & 0.532 \\
\hline
\end{tabular}

- Scores in the table are the means of answers on 5-point Likert-scales (5=Exactly correct, $3=\mathrm{A}$ toss-up, 1=Entirely incorrect). 
Table 5 Relationship between human resource management practices and adjustment \& job performance

\begin{tabular}{|c|c|c|c|c|c|c|}
\hline & \multicolumn{3}{|c|}{ Adjustment } & \multicolumn{3}{|c|}{ Job performance } \\
\hline & $\begin{array}{l}\text { Work } \\
\text { adjustment }\end{array}$ & $\begin{array}{l}\text { Interaction } \\
\text { adjustment }\end{array}$ & $\begin{array}{l}\text { General } \\
\text { adjustment }\end{array}$ & $\begin{array}{l}\text { Evaluation } \\
\text { by supervisors }\end{array}$ & $\begin{array}{l}\text { Evaluation by } \\
\text { colleagues and } \\
\text { subordinates }\end{array}$ & $\begin{array}{l}\text { Self- } \\
\text { evaluation }\end{array}$ \\
\hline \multicolumn{7}{|l|}{ Selection criteria } \\
\hline $\begin{array}{l}\text { Language ability and } \\
\text { familiarity with local } \\
\text { cultures }\end{array}$ & $0.304^{* *}$ & 0.174 & 0.072 & 0.114 & 0.149 & 0.110 \\
\hline $\begin{array}{l}\text { Technical or professional } \\
\text { competences }\end{array}$ & $0.185 \dagger$ & -0.015 & 0.142 & 0.125 & 0.081 & 0.015 \\
\hline $\begin{array}{l}\text { Leadership and relational } \\
\text { abilities }\end{array}$ & 0.056 & 0.144 & 0.015 & 0.182 & $0.210 \dagger$ & 0.156 \\
\hline Family situations & -0.137 & -0.081 & 0.024 & -0.101 & 0.077 & -0.054 \\
\hline \multicolumn{7}{|l|}{$\begin{array}{l}\text { Pre-departure } \\
\text { preparation programs }\end{array}$} \\
\hline $\begin{array}{l}\text { (Factor 1) } \\
\text { Provision of information } \\
\text { on local socio-economic } \\
\text { situations }\end{array}$ & 0.141 & -0.071 & 0.048 & -0.144 & -0.074 & -0.117 \\
\hline $\begin{array}{l}\text { (Factor 2) } \\
\text { Training on 'our company } \\
\text { way' }\end{array}$ & -0.011 & 0.027 & -0.031 & -0.145 & -0.051 & -0.183 \\
\hline $\begin{array}{l}\text { (Factor 3) } \\
\text { Provision of information } \\
\text { on the foreign subsidiary } \\
\text { of assignment and } \\
\text { confirmation of } \\
\text { significance of the } \\
\text { assignment as well as the } \\
\text { meanings in career path }\end{array}$ & 0.017 & -0.088 & -0.053 & -0.054 & -0.058 & 0.037 \\
\hline \multicolumn{7}{|l|}{$\begin{array}{l}\text { Supportive measures } \\
\text { while abroad }\end{array}$} \\
\hline $\begin{array}{l}\text { (Factor 1) } \\
\text { Interactive exchange of } \\
\text { information between } \\
\text { expatriates and the } \\
\text { headquarters }\end{array}$ & 0.052 & $0.300 * *$ & $0.218 *$ & $0.384 * * *$ & $0.381 * * *$ & $0.240^{*}$ \\
\hline $\begin{array}{l}\text { (Factor 2) } \\
\text { Measures to promote } \\
\text { cross-cultural } \\
\text { understanding and to } \\
\text { improve foreign language } \\
\text { ability }\end{array}$ & 0.013 & 0.006 & 0.023 & 0.075 & -0.129 & 0.046 \\
\hline $\begin{array}{l}\text { (Factor } 3 \text { ) } \\
\text { Information sharing and } \\
\text { mutual support among } \\
\text { Japanese expatriates }\end{array}$ & $0.244 * *$ & 0.119 & $0.191^{*}$ & $0.232 * *$ & 0.062 & -0.070 \\
\hline \multicolumn{7}{|l|}{ Dummies } \\
\hline $\begin{array}{l}\text { Location of assignment } \\
(\text { Other Asia }=1 \text {, others }=0)\end{array}$ & $0.265^{* *}$ & 0.140 & $0.319 * *$ & 0.112 & 0.119 & 0.056 \\
\hline $\begin{array}{l}\text { Location of assignment } \\
\text { (North America=1, } \\
\text { others }=0 \text { ) }\end{array}$ & 0.082 & -0.108 & 0.085 & 0.147 & 0.072 & 0.081 \\
\hline $\begin{array}{l}\text { Location of assignment } \\
\text { (Europe }=1 \text {, others }=0 \text { ) }\end{array}$ & 0.080 & 0.085 & 0.126 & 0.082 & 0.110 & -0.019 \\
\hline The number of times of & 0.086 & 0.112 & $0.161 \dagger$ & -0.128 & -0.118 & -0.020 \\
\hline
\end{tabular}




\begin{tabular}{|l|l|l|l|l|l|l|}
\hline $\begin{array}{l}\text { foreign assignment (more } \\
\text { than twice=1, once=0) }\end{array}$ & & & & & & \\
\hline \hline Adjusted R2 & 0.333 & 0.121 & 0.192 & 0.243 & 0.204 & 0.027 \\
\hline F-value & $5.484^{* * *}$ & $2.241^{*}$ & $3.135^{* * *}$ & $3.885^{* * *}$ & $3.302^{* * *}$ & 1.249 \\
\hline
\end{tabular}

Table 6 Relationship between adjustment and job performance

\begin{tabular}{|l|l|l|l|}
\hline & $\begin{array}{l}\text { Evaluation by } \\
\text { supervisors }\end{array}$ & $\begin{array}{l}\text { Evaluation by } \\
\text { colleagues and } \\
\text { subordinates }\end{array}$ & Self-evaluation \\
\hline Work adjustment & $0.412^{* * *}$ & $0.426^{* * *}$ & $0.310^{* * *}$ \\
\hline Adjusted R2 & 0.164 & 0.176 & 0.090 \\
\hline F-Value & $30.035^{* * *}$ & $32.676^{* * *}$ & $15.6444^{* * *}$ \\
\hline $\begin{array}{l}\text { Interaction } \\
\text { adjustment }\end{array}$ & $0.358^{* * *}$ & $0.392^{* * *}$ & $0.316^{* * *}$ \\
\hline Adjusted R2 & 0.122 & 0.148 & 0.094 \\
\hline F-Value & $21.551^{* * *}$ & $26.730^{* * *}$ & $16.321^{* * *}$ \\
\hline \hline General adjustment & $0.442^{* * *}$ & $0.350^{* * *}$ & $0.215^{* *}$ \\
\hline Adjusted R2 & 0.190 & 0.116 & 0.040 \\
\hline F-Value & $35.737^{* * *}$ & $20.498^{* * *}$ & $7.135^{* *}$ \\
\hline
\end{tabular}




\section{Appendices}

Appendix 1 Factor analysis of pre-departure preparation programs

\begin{tabular}{|l|r|r|r|}
\hline $\begin{array}{l}\text { Training or provision of information on living in the country of } \\
\text { assignment }\end{array}$ & \multicolumn{1}{|c|}{ Factor 1 } & \multicolumn{1}{|c|}{ Factor 2} & Factor 3 \\
\hline Training or provision of information on local cultures or values & 0.795 & 0.133 & 0.188 \\
\hline $\begin{array}{l}\text { Training or provision of information on risk management or } \\
\text { securities }\end{array}$ & 0.699 & 0.410 & 0.157 \\
\hline $\begin{array}{l}\text { Training or provision of information on local personnel } \\
\text { management or labor management relations }\end{array}$ & 0.675 & 0.205 & 0.352 \\
\hline $\begin{array}{l}\text { Advice or provision of information from former expatriates to } \\
\text { the country of assignment }\end{array}$ & 0.585 & 0.132 & 0.253 \\
\hline $\begin{array}{l}\text { Training or provision of information on our basic principles of } \\
\text { CSR }\end{array}$ & 0.131 & 0.900 & 0.118 \\
\hline $\begin{array}{l}\text { Training or provision of information on our basic principles of } \\
\text { personnel management or labor management relations }\end{array}$ & 0.425 & 0.673 & 0.170 \\
\hline $\begin{array}{l}\text { Training or provision of information on our corporate philosophy } \\
\text { or code of conduct }\end{array}$ & 0.117 & 0.623 & 0.218 \\
\hline $\begin{array}{l}\text { Training or provision of information on business situations, } \\
\text { management policies and practices of the foreign subsidiary of } \\
\text { assignment }\end{array}$ & 0.253 & 0.148 & 0.816 \\
\hline $\begin{array}{l}\text { Explanation of the assignment and roles as well as } \\
\text { responsibilities and authorities }\end{array}$ & 0.128 & 0.186 & 0.686 \\
\hline Explanation of the meanings of the assignment in career path & 0.297 & 0.335 & 0.514 \\
\hline Eigenvalue & 5.979 & 1.464 & 1.338 \\
\hline Contribution & $42.71 \%$ & $10.46 \%$ & $9.56 \%$ \\
\hline
\end{tabular}

- Factors with eigenvalue of 1.00 or higher were used. Rotation=varimax.

Appendix 2 Factor analysis of measures while abroad

\begin{tabular}{|c|c|c|c|}
\hline & Factor 1 & Factor 2 & Factor 3 \\
\hline Support system for risk management or securities & 0.715 & 0.311 & 0.169 \\
\hline $\begin{array}{l}\text { Provision of real-time information on the latest management } \\
\text { policies or technical trends at the headquarters }\end{array}$ & 0.647 & 0.185 & -0.051 \\
\hline $\begin{array}{l}\text { Opportunities to make a request on face-to-face basis such as } \\
\text { regular visits by personnel department or labor union of the } \\
\text { headquarters }\end{array}$ & 0.590 & 0.219 & 0.268 \\
\hline Feedback on the result of personnel evaluation & 0.577 & 0.018 & 0.178 \\
\hline $\begin{array}{l}\text { Supportive measures of healthcare such as the affiliation with } \\
\text { reliable local medical institutions }\end{array}$ & 0.510 & 0.233 & 0.187 \\
\hline Explanation of jobs or career prospects after repatriation & 0.503 & 0.416 & -0.089 \\
\hline Grant of paid leave to Japan & 0.458 & 0.027 & 0.030 \\
\hline $\begin{array}{l}\text { Supportive measures or provision of information on living in the } \\
\text { country of assignment }\end{array}$ & 0.441 & 0.381 & 0.296 \\
\hline $\begin{array}{l}\text { Existence of mentors or advisors at the headquarters (including } \\
\text { the regional headquarters) }\end{array}$ & 0.417 & 0.387 & 0.109 \\
\hline Training or provision of information on local cultures or values & 0.211 & $\overline{0.777}$ & 0.136 \\
\hline Supportive measures to improve language ability & 0.029 & 0.594 & 0.020 \\
\hline Transfer of duties or kick-off orientation & 0.088 & 0.010 & 0.791 \\
\hline $\begin{array}{l}\text { Advice or support from senior expatriates on the work and } \\
\text { living }\end{array}$ & 0.200 & 0.139 & 0.721 \\
\hline Eigenvalue & 4.748 & $\overline{\overline{1.536}}$ & $\overline{1.344}$ \\
\hline Contribution & $33.92 \%$ & $10.97 \%$ & $9.60 \%$ \\
\hline
\end{tabular}

- Factors with eigenvalue of 1.00 or higher were used. Rotation=varimax. 
